\title{
Eimeria spp. from Japanese quails (Coturnix japonica): new characteristic features and diagnostic tools ${ }^{1}$
}

\author{
Bruno P. Berto ${ }^{2 *}$, Helcio R. Borba ${ }^{2}$, Viviane M. Lima ${ }^{2}$, Walter Flausino ${ }^{3}$, Walter L. \\ Teixeira-Filho ${ }^{3}$ and Carlos Wilson G. Lopes ${ }^{3}$
}

\begin{abstract}
Berto B.P., Borba H.R., Lima V.M., Flausino W., Teixeira-Filho W.L. \& Lopes C.W.G. 2013. Eimeria spp. from Japanese quails (Coturnix japonica): new characteristic features and diagnostic tools. Pesquisa Veterinária Brasileira 33(12):1441-1447. Departamento de Biologia Animal, Instituto de Biologia, Universidade Federal Rural do Rio de Janeiro, Seropédica, RJ 23897-970, Brazil. E-mail: bertobp@ufrrj.br

The Japanese quail Coturnix japonica originated from North Africa, Europe and Asia, is used worldwide as an experimental animal and model for aviculture. The current paper characterizes Eimeria bateri, Eimeria tsunodai and Eimeria uzura recovered from C. japoni$c a$. Based on the fact that quails have a global distribution, as are their coccidia, the findings of this study should provide the means for diagnosis of those Eimeria spp. in other regions and continents. Eimeria bateri showed the greatest intensity of infection and shed oocysts from the fourth day after infection; in contrast, E. tsunodai and E. uzura shed oocysts from the fifth day after infection. The three species shared a high degree of similarity and were all polymorphic. Yet, the application of line regressions, histograms and ANOVA provided means for the identification of these species. Finally, the algorithm was very efficient since verified that resultant values were not superimposed.
\end{abstract}

INDEX TERMS: Coccidiosis, diagnostic, Eimeria bateri, Eimeria tsunodai, Eimeria uzura.

RESUMO.- [Eimeria spp. de codornas japonesas (Coturnix japonica): novas características e ferramentas de diagnóstico.] A codorna japonesa Coturnix japonica originária do norte da África, Europa e Ásia, é utilizada mundialmente como um animal experimental e modelo para avicultura. 0 presente trabalho caracteriza Eimeria bateri, Eimeria tsunodai e Eimeria uzura recuperadas de C. japoni$c a$. Baseado no fato de que as codornas têm uma distribuição global, como são os seus coccídios, os resultados deste estudo devem propiciar o diagnóstico destas Eimeria spp. em outras regiões e continentes. Eimeria bateri demonstrou a maior intensidade de infecção e eliminaram oocistos a partir do quarto dia após infecção, em contraste E. tsunodai e E. uzura eliminaram oocistos a partir do quinto dia

\footnotetext{
${ }^{1}$ Received on September 17, 2013.

Accepted for publication on November 5, 2013.

${ }^{2}$ Departamento de Biologia Animal, Instituto de Biologia, Universidade Federal Rural do Rio de Janeiro (UFRRJ), BR-465 Km 7, Seropédica, RJ 23897-970, Brazil. E-mails: borba@ufrrj.br, vilima@ufrrj.br; *Corresponding author: bertobp@ufrrj.br

${ }^{3}$ Departamento de Parasitologia Animal, Instituto de Veterinária, UFRRJ, Seropédica, RJ. E-mails: flausino@ufrrj.br, leira@ufrrj.br, lopescwg@ufrrj.br - CNPq fellowship.
}

após infecção. As três espécies foram morfometricamente semelhantes e polimórficas. No entanto, a aplicação da regressão linear, histogramas e ANOVA proveram meios para a identificação destas espécies. Finalmente, o algoritmo foi totalmente eficiente uma vez que valores resultantes não foram sobrepostos.

TERMOS DE INDEXAÇÃO: Coccidiose, diagnóstico, Eimeria bateri, Eimeria tsunodai, Eimeria uzura.

\section{INTRODUCTION}

The breeding of Japanese quails Coturnix japonica has excelled in aviculture, due to increased consumption of exotic meats and eggs, and represents an alternative to chicken production. In the USA, Japanese quails were introduced in the 1950s, and at that time the breeding of Japanese quails was already widespread in European countries. In Brazil, Japanese quails were introduced in the 1950s, but large scale production began in the mid 1960's (Howes 1964, Murakami \& Ariki 1998, IUCN 2013, Jatoi et al. 2013).

In addition to its importance for aviculture, the Japanese quail has become, in recent decades, an important experimental animal for scientific research. It is used extensively in studies examining genetics, nutrition, toxicology, em- 
bryology, physiology and pathology (Shellenberger 1968, Ichilcik \& Austin 1978, Rao et al. 1990, 1995, Berto et al. 2008, Cardozo et al. 2010, Jatoi et al. 2013). The small size of Japanese quail relative to other species of poultry serves to reduce feed costs. It has a short life cycle, during which it lays a large quantity of eggs and shows greater resistance to many poultry diseases (Shellenberger 1968, Ichilcik \& Austin 1978, Rao et al. 1990, 1995, Berto et al. 2008, Cardozo et al. 2010, Jatoi et al. 2013).

In common with the situation encountered in breeding of other poultry species, parasitoses represent a limiting factor in high-production commercial rearing farms and even in rustic breeding systems, where economic losses can be significant. Among the most pathogenic parasites, coccidiosis caused by species of Eimeria is distinguished by severe enteropathy, which promotes anorexia, decreased reproduction and posture in adults, and is responsible for high levels of mortality in young animals (Mazurkiewicz et al. 1967, Norton \& Pierce 1971, Tsunoda \& Muraki 1971, Ruff et al. 1984, Teixeira et al. 2004).

The present study characterizes three Eimeria spp. commonly encountered on farms breeding Japanese quails $C$. japonica, with focus on the dynamics of oocyst shedding and the provision of detailed morphological and morphometrical data. In addition, an algorithm designed to enable reliable identification of individual species of Eimeria during routine diagnosis of Japanese quail pathogens is proposed.

\section{MATERIALS AND METHODS}

\section{Japanese quails and facilities}

Eight one-day-old Japanese quails Coturnix japonica were obtained from a commercial rearing farm located inthe Municipality of Seropédica in the State of Rio de Janeiro, Brazil. The chicks were transported to the Federal Rural University of Rio de Janeiro (UFRRJ), and were reared and fed in a single cage without anticoccidial additives. Feed and water were administered ad libitum. Sample processing and data analysis, as described below, were conducted at the Laboratório de Coccídios e Coccidioses and in the Departamento de Biologia Animal (Biology area), both located at UFRRJ. This study was approved by UFRRJ Ethics Committee under protocol No. 333/2013.

\section{Eimeria spp.}

The adult Japanese quails from the commercial rearing farm used to provide the chicks were naturally parasitized by three species of Eimeria: Eimeria bateri (Bhatia et al., 1965), Eimeria tsunodai (Tsutsumi, 1972) and Eimeria uzura (Tsunoda et Muraki, 1971). An inoculum for experimental infection was produced by recovering and isolating oocysts from fecal samples of positive Japanese quails by flotation in Sheather's sugar solution (S.G. 1.20) according to the protocol of Duszynski \& Wilber (1997). The oocysts were preserved in a $2.5 \%(\mathrm{w} / \mathrm{v})$ solution of $\mathrm{K}_{2} \mathrm{Cr}_{2} \mathrm{O}_{7}$ to induce sporulation and maintained in a refrigerator $\left(2-5^{\circ} \mathrm{C}\right)$ until use. All eight Coturnix japonica chicks were inoculated at the age of 7 days, using inocula, quantified using a Neubauer chamber, containing approximately $6.5 \times 10^{4}$ sporulated oocysts per chick, at the approximate proportion of: $50 \%$ E. bateri; $25 \%$ E. tsunodai; and $25 \%$ E. uzura.

\section{Study of oocysts}

The number of oocysts shed in the feces was determined on days $2,3,4,5,7,9,11,14,16,18,21,23,25$ and 28 after infec- tion (DAI). Enumeration of oocysts per gram of feces (OoPG) was performed according to Menezes \& Lopes (1995), as modified by Cardozo et al. (2010).

Oocysts were examined microscopically using the technique described by Duszynski \& Wilber (1997). Morphological observations and measurements, given in micrometres, were made using a Carl Zeiss binocular microscope with an apochromatic oil immersion objective lens and an ocular micrometer (K-15X PZO) Poland. Line drawings were prepared using a Wild M-20 binocular microscope with a drawing tube. Photomicrographs were taken using a digital camera (Sony CD Mavica MVC-CD250). Size ranges are shown in parentheses followed by average and shape index (L/W ratio). Abbreviations: micropyle [M], oocyst residuum [OR], polar granule [PG], Stieda body [SB], substieda body [SSB], parastieda body [PSB], sporocyst residuum [SR], sporozoite [SZ], refractile body [SRB], nucleus [N], length [L] and width [W].

\section{Statistical evaluation}

Three statistical methods were employed: 1) Histograms were prepared to plot the values of the length, width and shape-index of the oocysts, as well as their relative frequencies, according to Sampaio (2002) and Berto et al. (2008, 2011); 2) Analysis of variance (ANOVA) was used to compare measurements of the length, width and shape-index of the oocysts and sporocysts of individual Eimeria spp. The software Microsoft@ Excel 2007 was used to calculate the mean, variance, degree of freedom and p value (Gomez et al. 1982, Sampaio 2002, Berto et al. 2011); 3) Linear regression to determine the distribution of Eimeria spp. sporulated oocysts using methods proposed by Norton \& Joyner (1981) and subsequently modified by Sampaio (2002) and Berto et al. (2011). The graphs and coefficient of regression line were obtained using the software Microsoft Excel $2007^{\circledR}$.

\section{Algorithm for identification}

Morphological and morphometrical characteristics from a total of 150 oocysts were analyzed to create an identification algorithm. The size of SSB and shape of the oocyst wall ends were estimated and transformed to numerical values (SSB appearance: $0=$ prominent, $0.5=$ barely discernible; Oocyst wall ends: 0 $=$ rounded ends, $0.7=$ one of the ends flattened). Thereafter, the following equation was developed to differentiate E. bateri, E. tsunodai and E. uzura:

$$
\mathrm{A}=\left(\mathrm{WO}_{\mathrm{LS}}\right)-\left(\mathrm{nPGX}{ }^{1} /{ }_{10}\right)+\mathrm{OWe}+\mathrm{SSBa}
$$

where $\mathrm{A}$ is the algorithm value, $\mathrm{WO}=$ width of oocyst, $\mathrm{LS}=$ length of sporocysts, $\mathrm{nPG}=$ number of $\mathrm{PG}, \mathrm{OWe}=$ oocyst wall ends, and $\mathrm{SSBa}=\mathrm{SSB}$ appearance.

\section{RESULTS \\ Dynamic of oocysts shedding}

Eimeria bateri oocysts were observed commencing on the fourth day after infection, whereas, oocysts of E. tsunodai and E. uzura were shed from the fifth day after infection (Fig. 1). Eimeria bateri demonstrated a greater intensity of infection shedding a total of 849,425 (71\%) oocysts, followed by E. tsunodai with 268,465 (22\%) and E. uzura with $77,718(7 \%)$ oocysts. It was observed that each Eimeria spp. showed four peaks of oocyst shedding until the 28th DAI, with some shedding periods being of extended duration and at different periods when the three species were compared (Fig.1). 


\section{Eimeria spp. oocysts characterization}

All the Japanese quails experimentally infected shed oocysts in feces. Initially, the oocysts were non-sporulated, by day three, $70 \%$ of them were sporulated.

Eimeria bateri (Bhatia et al. 1965). Oocysts $(n=50)$ (Figs. 2a,d-f. 3a-b) were sub-spheroidal to ellipsoidal. OW bi-layered and smooth, $\sim 1.0$ thick. $\mathrm{M}$ and OR absent, but one or two PG present. Sporocysts ovoidal. SB nipplelike, $\sim 1.0$ high $\times 1.5$ wide. SSB rounded, prominent, $\sim 1.0$ high $\times$ 2.0 wide. PSB absent. SR composed of granules of different sizes. SZ vermiform with single posterior SRB and centrally located $\mathrm{N}$. The morphometry of the sporulated oocysts of E. bateri can be vizualized in Table 1. The histograms and linear regressions can be seen in Figures 4a,d and 5 respectively.

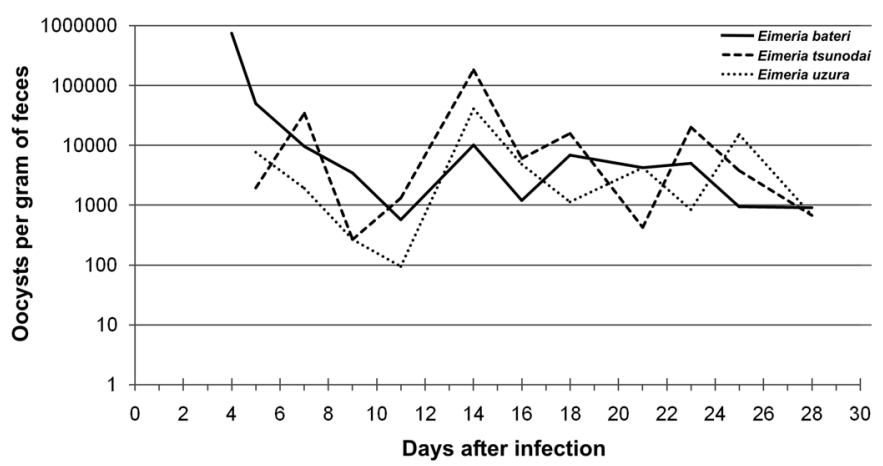

Fig.1. Dynamics of oocyst shedding of oocysts of Eimeria spp. recovered from experimentally infected Japanese quails Coturnix japonica. morphometry of the sporulated oocysts of E. tsunodai can be observed in Table 1 . The histograms and linear regressions can be visualized in Figures $4 \mathrm{~b}$,e and 5 respectively.

Eimeria uzura (Tsunoda et Muraki, 1971). Oocysts $(\mathrm{n}=50)$ (Figs. 2c,j-l, 3e-f) were ovoidal. OW bi-layered and smooth, $\sim 1.0$ thick. M and OR absent, but five or more PG present. Sporocysts elongate. SB knob-like to half-moonshaped, $\sim 0.5$ high $\times 1.5$ wide. SSB rounded, prominent, $\sim 1.0$ high $\times 2.0$ wide. PSB absent. SR composed of many granules. SZ vermiform with single posterior SRB and centrally located N. In Table 1, the morphometry of the sporulated oocysts of $E$. uzura can be visualized. The histograms and linear regressions can be visualized in Figures 4c,f and 5 respectively.

\section{Algorithm for identification}

The values obtained using the identification algorithm as applied to 150 eimerian oocysts identified in fecal samples of experimentally infected quails are presented Table 1. It was observed that the range of values obtained from the three Eimeria spp. were not superimposed, and in addition they showed significant differences between means.

\section{DISCUSSION}

Japanese quail are not a Brazilian species, having originating from North Africa, Europe and Asia, therefore the coccidia characterized in this work are not regional, but instead should represent those which parasitized the first lots of quails that were imported into Brazil in the 1950s (Howes 1964, Murakami \& Ariki 1998, IUCN 2013, Jatoi et al. 2013).
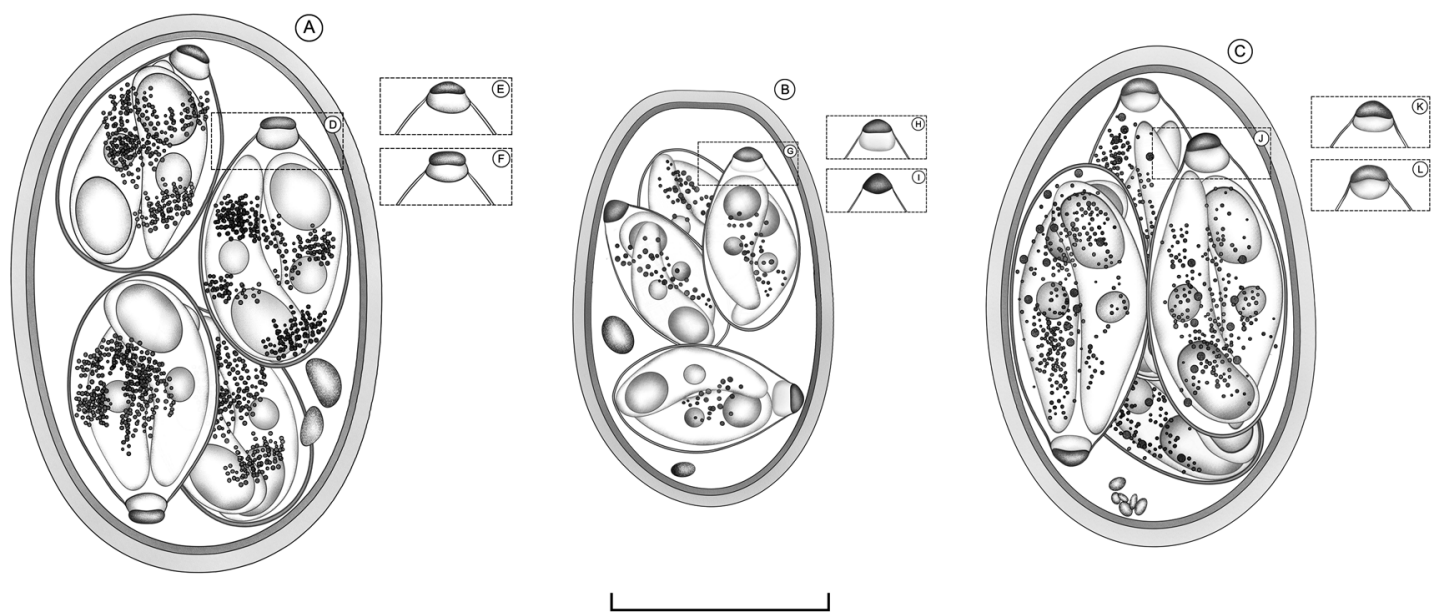

Fig.2. Composite line drawings of the sporulated oocysts of Eimeria spp. recovered from Japanese quails Coturnix japonica, with variations of Stieda and substieda bodies (D-L) detached: (A) Eimeira bateri; (B) Eimeira tsunodai; (C) Eimeira uzura. Scale bar: $10 \mu \mathrm{m}$.

Eimeria tsunodai (Tsutsumi, 1972). Oocysts $(n=50)$ (Figs. 2b,g-i, 3c-d) were sub-spheroidal to ellipsoidal. OW bi-layered, smooth and often with one end flattened, $\sim 1.0$ thick. M and OR absent, but one or two PG present. Sporocysts ovoidal. SB nipplelike to triangular, $\sim 0.5$ high $\times 1.5$ wide. SSB rectangular, barely discernible, $\sim 0.5$ high $\times 1.5$ wide. PSB absent. SR composed of few granules. SZ vermiform with single posterior SRB and centrally located N. The
In this context, these coccidia should have a worldwide distribution, and for that reason data from the current morphological and morphometric studies and the application of the algorithm should prove useful for the identification of these Eimeria spp. in other regions and continents. It is also worth considering that the Eimeria spp. characterized in this work, can be recovered, identified and used globally in experiments to assess their susceptibility to chemothe- 


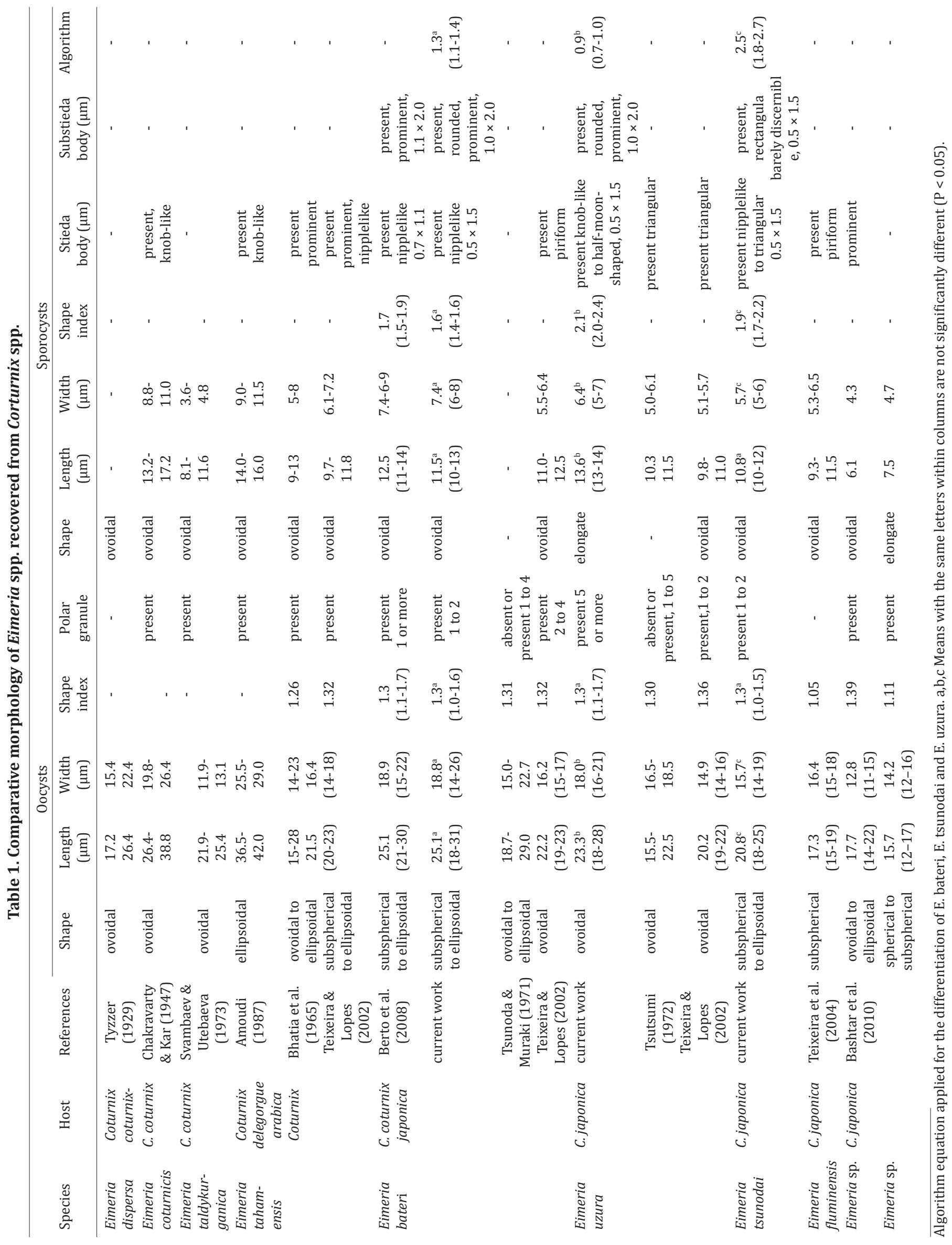




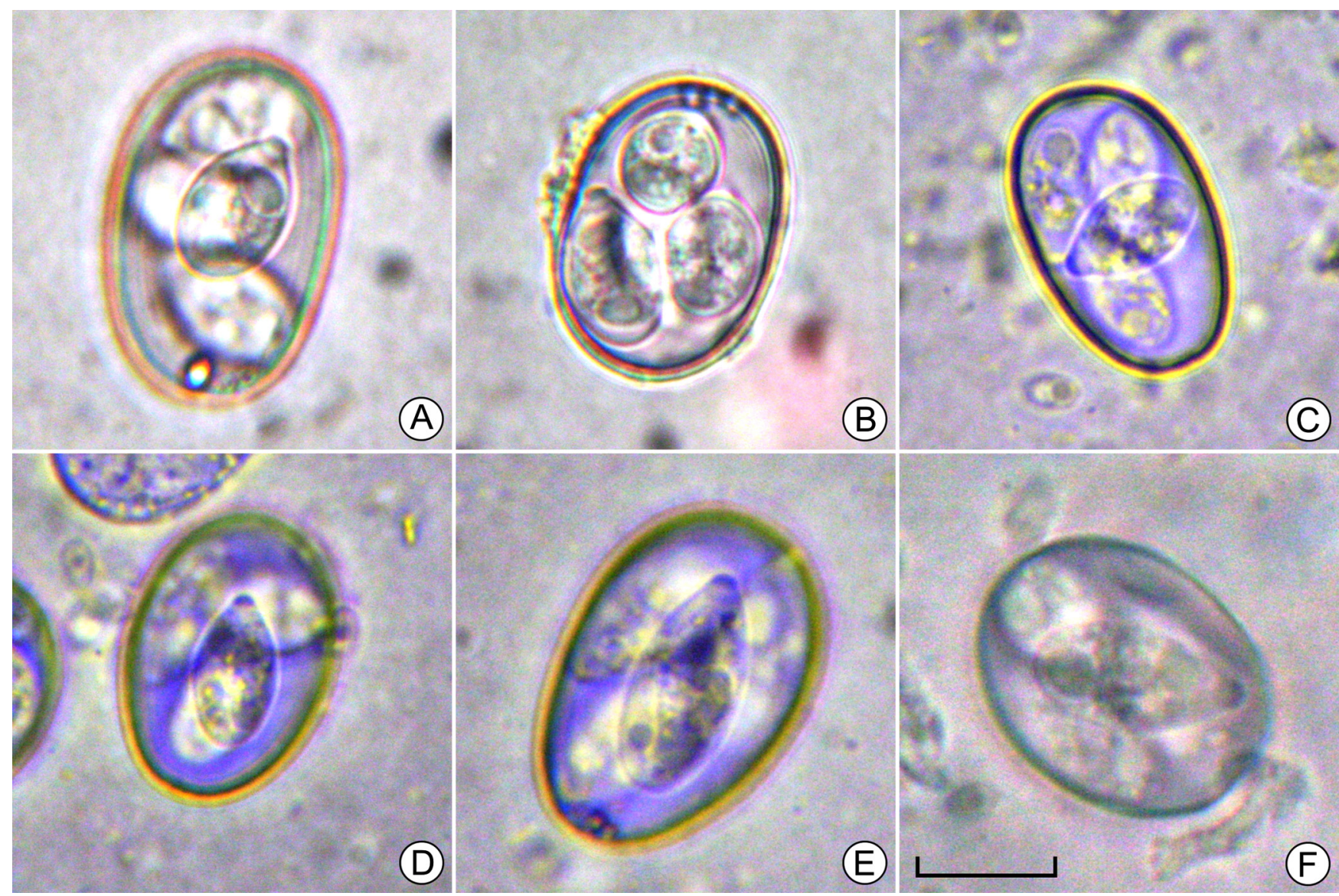

Fig.3. Photomicrographs of sporulated oocysts of Eimeria spp. recovered from Japanese quails Coturnix japonica: (A-B) Eimeira bateri; (C-D) Eimeira tsunodai; (E-F) Eimeira uzura. Scale-bar: $10 \mu \mathrm{m}$.

rapeutic drugs and herbal medicines, association with toxicity, etc. and as an experimental model for poultry (Shellenberger 1968, Ichilcik \& Austin 1978, Rao et al. 1990, 1995, Berto et al. 2008, Cardozo et al. 2010, Jatoi et al. 2013).

The prepatent periods recorded for the three Eimeria spp. from experimentally infected quails in this study (4 days for E. bateri, and 5 days for E. tsunodai and E. uzura) were similar to those described by Bhatia et al. (1965), Tsunoda \& Muraki (1971) and Bashtar et al. (2010). With regards to transmission, E. bateri appeared to be the most successful in mixed infections, based on the observation that it shed a greater quantity of oocysts during the experimental period (Fig.1).

Bhatia et al. (1965), Tsunoda \& Muraki (1971) and Tsutsumi (1972) described the three species characterized in this study, but did they lacked the current optical resources that allowed improved visualization and detailed descriptions of sporulated oocysts. Teixeira \& Lopes (2002) and Teixeira et al. (2004) described morphologic details of oocysts of these species, but some data essential for differentiation were not provided, such as flattening of one of the ends of the oocysts of E. tsunodai and the presence of SSB in all three species. Furthermore, in those articles the description of the SB as piriform in E. uzura and the SB as triangular in $E$. tsunodai was in fact making reference to the SB and SSB complex. More recently, Berto et al. (2008) reported oocysts of $E$. bateri similar to those described in the present study, but they did not characterize the species. Table 1 compares the morphology and morphometry of all Eimeira spp. recovered from Coturnix spp.

Morphometric data from the current study served to characterize the polymorphic nature of the oocysts of each of the three Eimeria spp., which was more pronounced for E. uzura and less so for E. bateri. This polymorphism could be verified using linear regression analysis (Fig.5), which demonstrated multiple variations for values of width on length, as evidenced by the low value of $\mathrm{R}^{2}$. Oocyst polymorphism has been described previously by several authors for a variety of coccidia and it is caused by different factors associated with the environment and host parasite relationship (Duszynski 1971, Catchpole et al. 1975, Fayer 1980, Joyner 1982, Gomez et al. 1982, Parker \& Duszynski 1986, Gardner \& Duszynki 1990, Berto et al. 2011). Importantly, the proximity of the regression lines and superimposed points demonstrated the inability to distinguish the three Eimeria spp. based solely on the length and width data (Fig.5), although ANOVA resulted in significant differences between length and width means (Table 1). In addition, some morphometric characteristics were evidenced in linear regression. The regression line was more inclined for E. bateri, which indicateds a tendency for the oocysts to adopt an ellipsoidal shape; E. bateri has larger oocysts which are separated from those of $E$. tsunodai and E. uzura in the graph (Fig.5). 

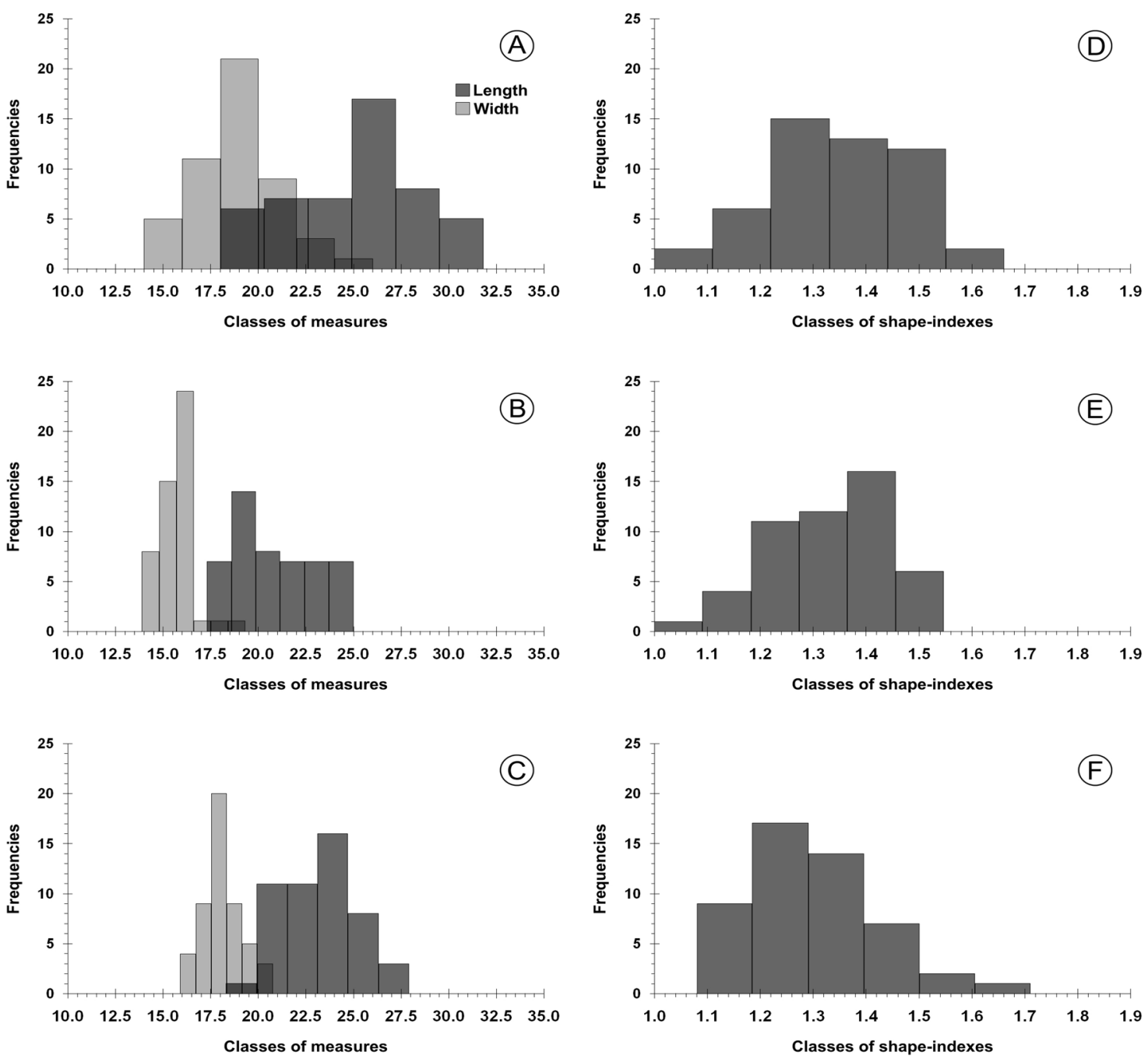

Fig.4. Histograms of the length and width and shape-index of the sporulated oocysts of Eimeria spp. from Japanese quails Coturnix japonica: (A,D) Eimeira bateri; (B,E) Eimeira tsunodai; (C,F) Eimeira uzura.

The histograms based on length and width data (Fig.4a-c) showed a regular distribution, besides revealing tendencies in the dimensions: $24.7-27.2 \times 18.0-20.0 \mu \mathrm{m}$ for $E$. bateri; $18.6-19.9 \times 15.7-16.6 \mu \mathrm{m}$ for E. tsunodai; and 23.1$24.7 \times 17.5-18.3 \mu \mathrm{m}$ for E. uzura. The histograms of shape-index (Fig.4d-f) revealed higher frequencies in the range of values from 1.2 to 1.5 for the three Eimeria spp. This observation indicated a tendency for the oocysts to adopt an ellipsoidal or ovoidal shape. In E. uzura specifically, it can be affirmed that there is no subspherical oocyst, since the values begin at 1.1 (Table 1, Fig.4f). Berto et al. (2011) observed similar aspects for Isospora spp. recovered from passerines birds on Marambaia Island in the State of Rio de Janeiro, Brazil.

The ANOVA applied for sporocysts also allows some morphometric comparisons (Table 1): Eimeria tsunodai and $E$. bateri have equivalent means of length and significant differences of width, readily justified by the greater width of $E$. bateri sporocysts; the equivalent means between the values of shape-indexes are also justified because the sporocysts are larger or smaller in the three Eimeria spp., however, the measures increased and decreased at the

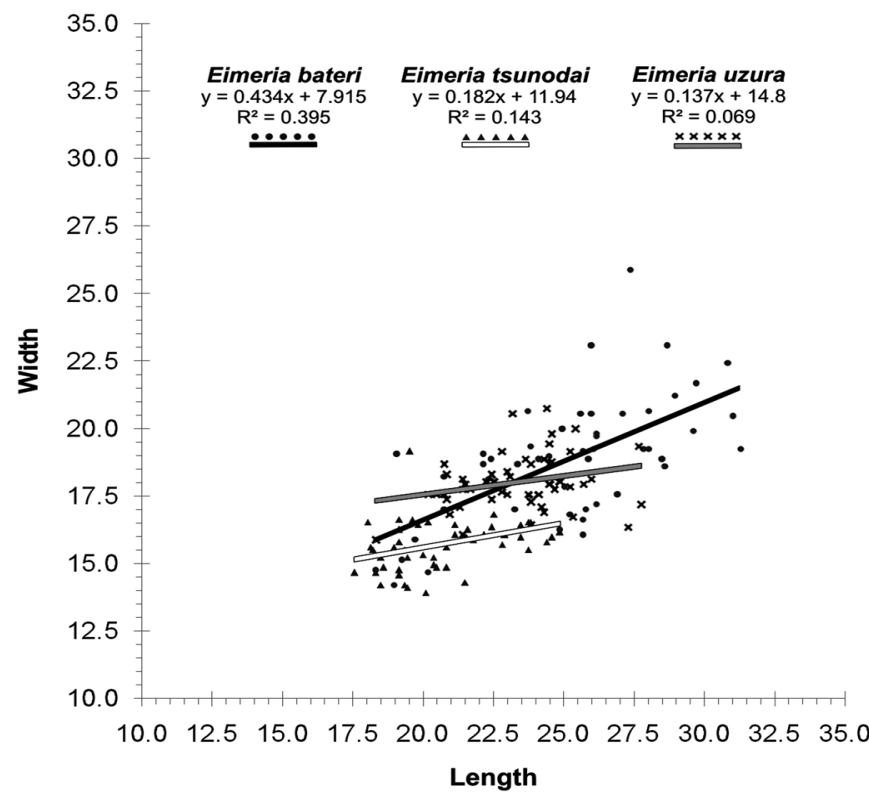

Fig.5. Comparative linear regressions of the sporulated oocysts of Eimeria spp. from Japanese quails (Coturnix japonica). 
same rate; and the significant differences of length among E. uzura and E. tsunodai and E. bateri conditioned part of the preparation of the algorithm through association with the oocyst width, which is not proportional in the three Eimeria spp.

The algorithm was completely efficient for the identification of oocysts, since it verified that species specific values did not superimpose following the application of the equation. Thus, values between 1.1 to 1.6 provided confident identification of $E$. bateri, whereas values lower than, or equal to, 1.0 supported the identification of E. uzura and values greater than or equal to 1.7 provided the identification of E. tsunodai. Algorithms for the differentiation of porcine Eimeria spp. dividing seven species into groups were implemented by Daugschies et al. (1999), and Hassum et al. (2007) created algorithms for the differentiation of Eimeria spp. from sheep. In the current research, the lower number of species $(n=3)$, allowed the creation of a single algorithm which was sufficiently robust for differentiation. Based on the successful application of this tool, we would encourage the developmentof more algorithms for identification of oocysts in other hosts.

Acknowledgements.- The study was supported by grants from the Fundação Carlos Chagas Filho de Amparo à Pesquisa do Estado do Rio de Janeiro (FAPERJ) to B.P. Berto (E-26/110.987/2013). We also thank the commercial rearing farm of Japanese quails at the Municipality of Seropédica in the State of Rio de Janeiro, Brazil, for permitting and assisting in the collection of material.

\section{REFERENCES}

Amoudi M.A. 1987. Eimeria tahamensis n. sp.(Apicomplexa: Eimeriidae) from the Arabian Quail (Coturnix delegorguei arabica). J. Protozool. 34: 455-456.

Bashtar A., Abdel-Ghaffar F., Al-Rasheid K., Mehlhorn H. \& Al-Nasr I. 2010. Light microscopic study on Eimeria species infecting Japanese quails reared in Saudi Arabian farms. Parasitol. Res. 107:409-416.

Bathia B.B., Pandey T.P. \& Pande B.P. 1965. Eimeria bateri n. sp. from Indian common quail (Coturnix coturnix). Ind. J. Microbiol. 5:61-64.

Berto B.P., Cardozo S.V., Teixeira-Filho W.L., Ferreira A.M.R. \& Lopes C.W.G. 2008. Aflatoxin effect on the oocysts morphometry and contribution on the morphology of Eimeria bateri Bhatia, Pandey and Pande, 1965 of the Japanese quail Coturnix japonica, in Brazil. Rev. Bras. Parasitol. Vet. 17:235-238.

Berto B.P., Luz H., Flausino W., Teixeira-Filho W.L., Ferreira I. \& Lopes C.W.G. 2011. Isosporoid Coccidia (Apicomplexa: Eimeriidae) parasites of tanagers (Passeriformes: Thraupidae) from the Marambaia Island, Brazil. Pesq. Vet. Bras. 31:798-805.

Cardozo S.V., Berto B.P., Ferreira A.M.R., Macedo H.W. \& Lopes C.W.G. 2010. Frequência de Eimeria bateri em codornas japonesas (Coturnix japonica) desafiadas com dose sub-letal de aflatoxina. Rev. Bras. Med. Vet. 32:211-214.

Catchpole J., Norton C. \& Joyner L. 1975. The occurrence of Eimeria weybridgensis and other species of coccidia in lambs in England and Wales. Brit. Vet. J. 131:392-401.

Chakravarty M. \& Kar A.B. 1947. A study on the coccidia of Indian birds. Proc. R. Soc. Edinburgh 62:225.

Daugschies A., Imarom S. \& Bollwahn W. 1999. Differentiation of porcine Eimeria spp. by morphologic algorithms. Vet. Parasitol. 81:201-210.

Duszynski D. 1971. Increase in size of Eimeria separata oocysts during patency. J. Parasitol. 57:948-952.

Duszynski D. \& Wilber P. 1997. A guideline for the preparation of species descriptions in the Eimeridae. J. Parasitol. 83:333-336.
Fayer R. 1980. Epidemiology of protozooan infection: the Coccidia. Vet. Parasitol. 6:75-103.

Gardner S. \& Duszynski D. 1990. Polymorphism of eimerian oocysts can be a problem in naturally infected hosts: an example from subterranean rodents in Bolivia. J. Parasitol. 76:805-811.

Gomez F., Navarrete I. \& Rodriguez R. 1982. Influencia de los factores ambientales sobre diferentes poblaciones de Isospora lacazei Labbé, 1983 (Protozoa: Apicomplexa). Revta Iber. Parasitol. 42:185-196.

Hassum I.C., Valladares G.S. \& De Menezes R.D.C.A. 2007. Diferenciação das espécies de Eimeria parasitas de ovinos pelo uso da regressão linear e algoritmos morfológicos. Revta Bras. Parasitol. Vet. 16:97-104.

Howes J.R. 1964. Managing Coturnix quail for research work. Quail Quart 1:31-40.

Ichilcik R. \& Austin J.C. 1978. The Japanese quail (Coturnix coturnix japoni$c a$ ) as a laboratory animal. J. South Afr. Vet. Assoc. 49:203-207.

IUCN 2013. International Union for Conservation of Nature and Natural Resources. http://www.iucnredlist.org. Assessed on July 4, 2013.

Jatoi A.S., Sahota A.W., Akram M., Javed K., Jaspal M.H., Hussain J., Mirani A.H. \& Mehmood S. 2013. Effect of different body weight categories on the productive performance of four close-bred flocks of japanese quails (Coturnix coturnix japonica). J. Anim. Prod. Sci. 23:7-13.

Joyner L. 1982. Host and Site specificity, p.35-62. In: Long P. (Ed.), The Biology of the Coccidia. University Park Press, Baltimore.

Mazurkiewicz M., Podlewska D. \& Wachnik Z. 1967. Kokcydioza u przepiórek japonskich. Med. Wet. 23:536-537.

Menezes R.C.A.A. \& Lopes C.W.G .1995. Epizootiologia da Eimeria arloingi em caprinos na microrregião Serrana Fluminense, Rio de Janeiro, Brasil. Revta Univ. Rural, Ciênc. Vida 17:5-12.

Murakami A.E. \& Ariki J. 1998. Produção de codornas japonesas. Fundação de Apoio a Pesquisa, Ensino e Extensão, Jaboticabal. 79p.

Norton C.C. \& Pierce M.A. 1971. The life cycle of Eimeria bateri (Protozoa: Eimeriidae) in the Japanese quail Coturnix japonica. J. Protozool. 18:57-62.

Norton C.C. \& Joyner L.P. 1981. Eimeria acervulina and E. mivati: oocysts, lifecycle and ability to develop in the chiken embryo. Parasitol. 83:269-279.

Parker B. \& Duszynski D. 1986. Polymorphism of eimerian oocysts: a dilemma posed by working with some naturally infected hosts. J. Parasitol. 72:602-604.

Rao J.R., Sharma N.N., Iyer P.K.R. \& Sharma A.K. 1990. Interaction between Eimeria uzura infection and aflatoxicosis in Japanese quail (Coturnix coturnix japonica). Vet. Parasitol. 35:259-267.

Rao J.R., Sharma N.N. \& Johri T.S. 1995. Influence of dietary aflatoxin on Eimeria uzura infection in Japanese quail (Coturnix coturnix japonica). Vet. Parasitol. 56:17-22.

Ruff M.D., Fagan J.M. \& Dick J.W. 1984. Pathogenicity of coccidians in the Japanese quail (Coturnix coturnix japonica). Poult. Sci. 63:55-60.

Sampaio I.B.M. 2002. Estatística aplicada à experimentação animal. FEP MVZ Editora, Belo Horizonte. 221p.

Shellenberger T.E. 1968. Biological studies utilizing Japanese quail. Lab. Anim. Care 18:244-249.

Svambaev S.K. \& Utebaeva M.K. 1973. Coccidial infections of Phasianus cochicus mongolicus and Coturnix coturnix in Kazakhstan. Izv. Akad. Nauk., Ser. Biol. 6:62-68.

Teixeira M. \& Lopes C.W.G. 2002. Species of the genus Eimeria (Apicomplexa: Eimeriidae) from Japanese quails (Coturnix japonica) in Brazil and E. fluminensis for the preoccupied E. minima of this quail. Revta Bras. Ciênc. Vet. 9:53-56.

Teixeira M., Teixeira-Filho W.L. \& Lopes C.W.G. 2004. Coccidiosis in japanese quails (Coturnix japonica): Characterization of a Naturally Ocurring Infection in a Commercial Rearing Farm. Revta Bras. Ciênc. Avíc. 6:129-134.

Tsunoda L. \& Muraki Y. 1971. A new coccidium of Japanese quails: Eimeria uzura n. sp. Japan. J. Vet. Sci. 33:227-235.

Tsutsumi Y. 1972. Eimeria tsunodai n. sp. (Protozoa: Eimeriidae): a caecal coccidium of Japanese quails (Coturnix japonica). Japan. J. Vet. Sci. 34:1-9.

Tyzzer E.E. 1929. Coccidiosis in gallinaceous birds. Am. J. Hygiene 10:269383. 